\title{
Interactive comment on "Abundance and viability of particle-attached and free-floating bacteria in dusty and nondust air" by Wei Hu et al.
}

Anonymous Referee \#3

Received and published: 24 May 2020

The comment was uploaded in the form of a supplement:

https://www.biogeosciences-discuss.net/bg-2020-94/bg-2020-94-RC3-supplement.pdf

Interactive comment on Biogeosciences Discuss., https://doi.org/10.5194/bg-2020-94, 2020. 